УдК 616-002 - 008.953-092

DOI 10.11603/2414-4533.2017.1.7628

(C) Р. І. ВЕРБА, І. М. КЛІЩ

ДВНЗ “Тернопільський державний медичний університет імені І. Я. Горбачевського”

\title{
Особливості кисень-залежних процесів у щурів з гострим поширеним перитонітом на тлі мерказоліліндукованого гіпотиреозу
}

\begin{abstract}
Мета роботи: дослідження впливу зниженої продукції тиреоїдних гормонів на стан кисень-залежних процесів.
Матеріали і методи. У роботі використовували білих щурів лінії Вістар. Гіпотиреоз моделювали уведенням мерказолілу в дозі 25 мг/кг протягом 21-ї доби. Гострий поширений перитоніт моделювали уведенням 0,5 мл 10 \% профільтрованої калової суспензії в черевну порожнину досліджуваних тварин. Визначали співвідношення фагоцитуючих клітин у місці ураження, продукування активних форм кисню системою фагоцитуючих мононуклеарів, спонтанний та індукований тест із нітросинім тетразолієм (НСТ-тест).

Результати досліджень та їх обговорення. Проведеними дослідженнями встановлено, що наявність гіпотиреозу в експериментальних тварин, яким моделювали гострий поширений каловий перитоніт, супроводжувалась порушенням співвідношення кількості фагоцитуючих клітин у місці ушкодження, менш вираженим, ніж в еутиреоїдних щурів, зростанням активних форм кисню, а також показників спонтанного та індукованого НСТ-тесту і, як наслідок, зменшенням інтенсивності продукування ними активних форм кисню. За умов гіпотиреозу знижується кисень-залежна біоцидність нейтрофілів та зменшуються функціональні резерви фагоцитуючих клітин.
\end{abstract}

Ключові слова: поширений перитоніт; гіпотиреоз; кисень-залежні процеси.

Постановка проблеми і аналіз останніх досліджень та публікацій. На тлі гіпотиреозу запальний процес, як системна відповідь організму, має певні особливості перебігу. Ці зміни зумовлені зниженням функціональної активності клітин, що беруть участь у формуванні запальної відповіді [8, 9,12,15].

Водночас перитоніт залишається однією із найважливіших проблем сучасної невідкладної хірургії. Незважаючи на суттєві досягнення в його діагностиці та лікуванні, результати терапії залишаються незадовільними, а летальність при цій патології - високою (20-90 \%) [1, 3]. Багато в чому це $\epsilon$ наслідком недостатньо вивчених патогенетичних механізмів, що задіяні при цій патології, зокрема швидко прогресуючої гіпоксії, порушення мікроциркуляції, активації процесів ліпопероксидації, зниження антиоксидантної активності клітин і тканин та розвитку уражень внутрішніх органів [19].

Перебіг перитоніту на тлі зниження функції щитоподібної залози має свої особливості. У роботі Alberti L. E. (2003) наведено навіть випадок спонтанного бактерійного перитоніту на тлі гіпотиреозу [10], що пояснюється особливостями ендокринного регулювання метаболічних процесів.

Дія екзогенних і ендогенних патогенів втягує в біологічну реакцію запалення не тільки імунокомпетентні органи, але й нейросекреторні клітини гіпоталамуса, які запускають перебудову функції ендокринної системи, спрямованої на адаптацію організму до умов патологічного процесу [9, 12].
Запальний процес супроводжується розвитком еутиреоїдного патофізіологічного стану, що становить, на думку ряду авторів [13], компенсаторну реакцію in vivo, адаптує всі соматичні клітини до наявного при запаленні дефіциту енергії. Прозапальні цитокіни, які продукують клітини імунної системи при запаленні, беруть участь у регуляції метаболізму тиреоїдних гормонів: інтерлейкін-6 (ІЛ-6) змінює периферійний метаболізм тиреоїдних гормонів, знижуючи експресію мРНК 5'-дейодинази і тим самим збільшуючи рівень менш активного тироксину [12]; ІЛ-12 і ІЛ-18 залучені в регуляцію продукції тиреоїдних гормонів на рівні центральних органів ендокринної системи, знижуючи рівень експресії рецепторів до тироксину і тиреотропного гормону в гіпоталамусі [12]. Гранулоцити, продукуючи активні метаболіти кисню, відіграють роль у периферійній утилізації тиреоїдних гормонів у хворих із запальними процесами, при яких збільшується рівень активних нейтрофілів. Активні метаболіти кисню здатні здійснювати йодизацію трийодтироніну до тироксину в присутності іонів йоду $[17,20]$.

3 метою вивчення кисень-залежного метаболізму клітин-ефекторів, що задіяні у перебігу запального процесу, ми використали модель гострого поширеного перитоніту на тлі експериментального гіпотиреозу.

Мета роботи: Оскільки динаміка і результат запального процесу багато в чому залежать від функціональної активності поліморфноядерних лейкоцитів, сануюча активність яких передусім 
зумовлена продукцією активних метаболітів кисню, метою цієї роботи стало дослідження впливу зниженої продукції тиреоїдних гормонів на стан кисень-залежних процесів.

Матеріали і методи. Для вивчення особливостей перебігу гострого перитоніту на тлі гіпотиреозу використовували білих щурів-самців лінії Вістар, які утримувалися на стандартному раціоні віварію при вільному доступі до води відповідно до вимог “Правил проведення робіт з використанням експериментальних тварин” [7]. У кожну експериментальну групу методом випадкової вибірки було включено по 12 тварин ма-

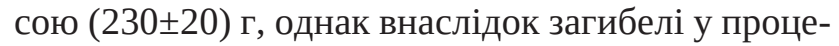
сі експерименту їх кількість у групах на момент евтаназії була різною. Всього у дослідженні було використано 120 тварин.

Гіпотиреоз моделювали щоденним введенням per os за допомогою зонда фармакопейного тиреостатика мерказолілу (“Здоров’я”, Україна) у дозі 25 мг/кг протягом 21-ї доби [15]. Повноту досягнення гіпотиреозу контролювали вимірюванням концентрації трийодтироніну і тироксину в сироватці крові, а також за динамікою маси тварин і їx рухової активності.

Вплив гіпотиреозу на перебіг гострого поширеного перитоніту вивчали на моделі, запропонованій Лазаренком В. А. і співавт., 2008 [5], що близька за етіологічними чинниками, клінічними проявами і фазністю перебігу до аналогічного процесу в людини і дозволяє отримувати загибель тварин, яка $є$ прийнятною для проведення динамічного дослідження протягом 10-ти діб. Це забезпечується уведенням 0,5 мл 10 \% профільтрованої калової суспензії в черевну порожнину досліджуваних щурів. Суспензію отримували шляхом змішування ізотонічного розчину і калу зі сліпої кишки двох-трьох інтактних тварин, потім її двічі фільтрували через подвійний шар марлі. Отриману суспензію не пізніше ніж через 20 хв після приготування вводили інтактним тваринам пункційним способом. Щоб уникнути пошкодження внутрішніх органів при введенні калової суспензії в черевну порожнину, тварин тримали вертикально, каудальним кінцем вгору. Методом пункції вентральної стінки в центрі середньої лінії живота, направляючи кінець голки по черзі у праве і ліве підребер’я, праву і ліву клубові ділянки, вводили однакову кількість калової суспензії.

Експериментальних тварин поділили на 4 групи:

- інтактні тварини, яким перорально вводили дистильовану воду протягом 21-ї доби;
- тварини, яким моделювали гіпотиреоз шляхом перорального уведення мерказолілу в дозі 25 мг/кг протягом 21-ї доби;

- тварини, яким моделювали гострий каловий перитоніт;

- тварини, яким моделювали гострий каловий перитоніт на тлі попередньо змодельованого гіпотиреозу.

Для дослідження використовували цільну кров, сироватку крові та гомогенат печінки. Тварин декапітували під тіопенталовим наркозом через 24 год, на 4-ту, 7-му і 10-ту доби від моменту початку моделювання перитоніту.

Вміст загального тироксину $\left(\mathrm{T}_{4}\right)$ і загального трийодтироніну $\left(\mathrm{T}_{3}\right)$ у сироватці визначали імунофлуоресцентним методом з використанням стандартних тест-наборів “Immulite 1000”. Концентрацію гормонів виражали в пмоль/л. Продукцію активних форм кисню (АФК) визначали методом проточної цитофлуориметрії на апараті Ерісs XL (“BeckmanCoulter") 3 використанням барвника дихлорфлюоресцеїну діацетат (ДХФ-ДА) (“Sigma Aldrich”). Значення досліджуваного параметра виражали в умовних одиницях (інтенсивність світіння на клітину). Мазки-відбитки перитонеальних оболонок фіксували у розчині азур-еозину, після чого заливали дистильованою водою на 15 хв, змивали залишки барвника проточною водою i висушували препарати. Мікроскопію зафарбованого препарату проводили за допомогою бінокулярного мікроскопа “Nikon” при збільшенні у 300 разів. Функціональну активність нейтрофілів оцінювали за допомогою спонтанного НСТ-тесту (сНСТ-тест) [4]. Результат виражали у відсотках диформазан-позитивних нейтрофілів від загального числа підрахованих клітин. Для визначення функціонального резерву нейтрофілів використовували індукований НСТ-тест (іНСТ-тест), для цього в середовище інкубації додатково додавали 0,05 мл пірогеналу. Результат виражали у відсотках диформазан-позитивних нейтрофілів на 100 нейтрофілів. Розраховували також показник резерву (ПР) за формулою іНСТ/сНСТ, а також коефіцієнт метаболічної активації нейтрофілів $\left(\mathrm{K}_{\text {акт }}\right)$ за формулою: iНCT - cHCT/iHCT [2]. Статистичну обробку цифрових даних здійснювали за допомогою програмного забезпечення "Excel” та "STATISTICA" із використанням параметричних і непараметричних методів оцінки отриманих даних. Для всіх показників розраховували значення середньої арифметичної вибірки (М), її дисперсії і помилки середньої (m). Достовірність різниці значень між незалежними кількісними величинами визначали при нормальному розподілі 
за t-критерієм Стьюдента, в інших випадках - за допомогою U-критерію Манна-Уїтні (достовірним вважали відмінності при р<0,05) [6].

Результати досліджень та їх обговорення. Для оцінки функціонального стану щитоподібної залози при моделюванні гіпотиреозу були визначені концентрації тиреоїдних гормонів у крові. Концентрація тироксину у здорових щурів склала $(17,70 \pm 0,58)$ пмоль/л, а у тварин, яким вводили мерказоліл, показник був знижений у 2,9 раза і становив $(8,96 \pm 0,26)$ пмоль/л. Концентрація $\mathrm{T}_{3}$ в інтактних щурів склала $(6,30 \pm 0,14)$ пмоль/л, а після уведення мерказолілу зменшилась у 2 рази від показника інтактних щурів і склала $(3,09 \pm 0,08)$ пмоль/л. Ми спостерігали також суб'єктивні ознаки гіпотиреозу - зменшення рухливості, інтенсивніше, ніж в інтактних тварин, зростання маси тіла, зміни шерсті. Це вказує на розвиток у тварин явищ гіпотиреозу внаслідок тривалого уведення мерказолілу в дозі 25 мг/кг.

На початковому етапі роботи порівнювали співвідношення кількості макрофагів і нейтрофілів у пародонті і кисень-залежну біоцидність нейтрофілів периферичної крові в інтактних щурів і в щурів з експериментальним гіпотиреозом. У групі тварин зі зниженою продукцією тиреоїдних гормонів відсоткове співвідношення макрофагів i нейтрофілів у мазках-відбитках перитонеальних оболонок достовірно не відрізнялося від такого в інтактних щурів (табл. 1).

Дослідження кисень-залежної біоцидності нейтрофілів (табл. 2) також не виявило відмінностей у показниках сНСТ-тесту в щурів з експериментальним гіпотиреозом, але при стимулюванні пірогеналом кількість диформазан-по-

Таблиця 1. Співвідношення фагоцитуючих клітин у мазках-відбитках перитонеальних оболонок щурів із гострим перитонітом на тлі гіпотиреозу $(\mathrm{M} \pm \mathrm{m})$

\begin{tabular}{|c|c|c|c|c|}
\hline \multirow{2}{*}{\multicolumn{2}{|c|}{ Група тварин }} & \multicolumn{3}{|c|}{ П Показник } \\
\hline & & нейтрофіли, \% & макрофаги, \% & макрофаги/ нейтрофіли, ум. од. \\
\hline \multicolumn{2}{|c|}{ Інтактні, $\mathrm{n}=12$} & $41,25 \pm 2,30$ & $58,75 \pm 2,19$ & $1,42 \pm 0,11$ \\
\hline \multicolumn{2}{|c|}{ Гіпотиреоз, n=12 } & $44,67 \pm 2,28$ & $55,33 \pm 2,13$ & $1,24 \pm 0,10$ \\
\hline \multirow{4}{*}{ 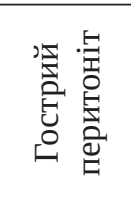 } & 24 год, $\mathrm{n}=10$ & $50,90 \pm 2,35^{*}$ & $49,10 \pm 2,11^{*}$ & $0,96 \pm 0,06^{*}$ \\
\hline & 4-та доба, n=9 & $52,41 \pm 1,82^{*}$ & $47,59 \pm 2,17^{*}$ & $0,91 \pm 0,07^{*}$ \\
\hline & 7-ма доба, n=7 & $58,67 \pm 2,11^{*}$ & $41,33 \pm 1,94^{*}$ & $0,70 \pm 0,06^{*}$ \\
\hline & 10-та доба, n=6 & $55,32 \pm 1,42^{*}$ & $44,68 \pm 2,14^{*}$ & $0,81 \pm 0,07^{*}$ \\
\hline \multirow{4}{*}{ 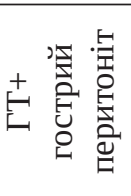 } & 24 год, $\mathrm{n}=12$ & $65,38 \pm 2,14^{* \#}$ & $34,62 \pm 2,11^{* \#}$ & $0,53 \pm 0,04^{* \#}$ \\
\hline & 4-та доба, $\mathrm{n}=8$ & $62,73 \pm 2,21^{* \#}$ & $37,27 \pm 2,17^{* \#}$ & $0,60 \pm 0,05^{* \#}$ \\
\hline & 7-ма доба, n=6 & $59,76 \pm 1,93^{* \#}$ & $40,24 \pm 1,94^{* \#}$ & $0,67 \pm 0,06^{* \#}$ \\
\hline & 10-та доба, n=5 & $56,75 \pm 1,78^{* \#}$ & $43,25 \pm 1,37^{* \#}$ & $0,76 \pm 0,06^{* \#}$ \\
\hline
\end{tabular}

Примітка. Тут і у таблиці 2: * - зміни показників еутиреоїдних і гіпотиреоїдних тварин із гострим перитонітом достовірні відносно інтактних; \# - зміни показників гіпотиреоїдних тварин із гострим перитонітом достовірні відносно показників еутиреоїдних на відповідні доби дослідження.

Таблиця 2. Показники активності кисень-залежних процесів у щурів із гострим перитонітом на тлі гіпотиреозу $(\mathrm{M} \pm \mathrm{m})$

\begin{tabular}{|c|c|c|c|c|c|c|}
\hline \multirow{2}{*}{\multicolumn{2}{|c|}{ Група тварин }} & \multicolumn{5}{|c|}{ Показник } \\
\hline & & АФК, ум. од. & сНСТ-тест, \% & іНСТ-тест, \% & ПР & $\mathrm{K}_{\text {акт }}$ \\
\hline \multicolumn{2}{|c|}{ Інтактні, n=12 } & $0,366 \pm 0,005$ & $16,15 \pm 0,91$ & $27,01 \pm 0,96$ & $1,65 \pm 0,06$ & $0,39 \pm 0,02$ \\
\hline \multicolumn{2}{|c|}{ Гіпотиреоз, n=12 } & $0,246 \pm 0,004^{*}$ & $17,91 \pm 0,49$ & $26,84 \pm 0,73$ & $1,47 \pm 0,05$ & $0,32 \pm 0,03^{*}$ \\
\hline \multirow{4}{*}{ 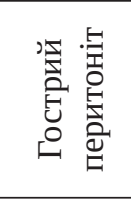 } & 24 год, n=10 & $0,838 \pm 0,014^{*}$ & $27,22 \pm 0,76^{*}$ & $38,50 \pm 0,57^{*}$ & $1,43 \pm 0,05^{*}$ & $0,29 \pm 0,02^{*}$ \\
\hline & 4-та доба, n=9 & $0,732 \pm 0,006^{*}$ & $22,28 \pm 0,82^{*}$ & $29,97 \pm 0,91^{*}$ & $1,37 \pm 0,04^{*}$ & $0,23 \pm 0,02^{*}$ \\
\hline & 7-ма доба, n=7 & $0,686 \pm 0,003^{*}$ & $22,80 \pm 0,36^{*}$ & $27,61 \pm 0,80$ & $1,20 \pm 0,04^{*}$ & $0,17 \pm 0,02^{*}$ \\
\hline & 10-та доба, n=6 & $0,417 \pm 0,005^{*}$ & $20,50 \pm 0,49^{*}$ & $32,61 \pm 1,09^{*}$ & $1,57 \pm 0,07$ & $0,36 \pm 0,01$ \\
\hline \multirow{4}{*}{ 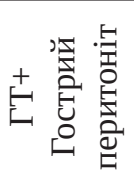 } & 24 год, n=12 & $0,316 \pm 0,004^{* \#}$ & $19,21 \pm 0,50^{* \#}$ & $25,42 \pm 0,37^{\#}$ & $1,33 \pm 0,03^{* \#}$ & $0,24 \pm 0,02^{*}$ \\
\hline & 4-та доба, $n=8$ & $0,513 \pm 0,006^{* \#}$ & $14,53 \pm 0,23^{\#}$ & $22,95 \pm 0,43^{* \#}$ & $1,58 \pm 0,04^{\#}$ & $0,31 \pm 0,02^{* \#}$ \\
\hline & 7-ма доба, n=6 & $0,629 \pm 0,010^{*}$ & $14,35 \pm 0,34^{\#}$ & $22,61 \pm 0,72^{* \#}$ & $1,57 \pm 0,08^{\#}$ & $0,33 \pm 0,02^{\#}$ \\
\hline & 10-та доба, n=5 & $0,658 \pm 0,011^{* \#}$ & $14,08 \pm 0,61^{\#}$ & $22,44 \pm 0,89^{* \#}$ & $1,59 \pm 0,09$ & $0,32 \pm 0,04$ \\
\hline
\end{tabular}


зитивних нейтрофілів була на 11 \% меншою, ніж в інтактних тварин. Коефіцієнт активації у щурів з гіпотиреозом також був на $12 \%$ нижчим ( $<0,05)$, ніж в еутиреоїдних щурів. Рівень активних форм кисню у тварин із гіпотиреозом становив $68 \%(\mathrm{p}<0,05)$ від показника інтактних тварин, що можна вважати наслідком зниження активності метаболічних процесів, у тому числі й тих, які супроводжуються продукцією активних форм кисню, за умов дефіциту гормонів щитоподібної залози.

Запальний процес в очеревині еутиреоїдних щурів із першої доби супроводжувався розвитком оксидативного стресу та зростанням інтенсивності продукування активних форм кисню (в 2,3 раза відносно здорових тварин). Це стало наслідком зростання кількості активних нейтрофілів у периферійній крові. Зокрема, показник спонтанного НСТ-тесту зріс на 70 \% від рівня інтактних тварин. Стимулювання пірогеналом супроводжувалось дещо меншим зростанням кількості диформазан-позитивних клітин - на $43 \%(\mathrm{p}<0,05)$, що відображає зниження функціональних резервів поліморфноядерних нейтрофілів, характерне для запального процесу. На це вказує також достовірне зниження показника резерву (на 15 \%) та коефіцієнта активування (на $13 \%$ ). Активування нейтрофілів супроводжувалась їх надходженням у вогнище ураження, на що вказує достовірне зниження (в 1,5 раза) співвідношення макрофаги/нейтрофіли (табл. 1).

До 4-ї доби показник співвідношення макрофаги/нейтрофіли дещо зменшився відносно попереднього терміну спостереження та був достовірно нижчим, ніж в інтактних тварин. Спонтанний НСТ-тест також зменшився відносно 1-ї доби і склав 138 \% від рівня здорових тварин. Значно більше зниження іНСТ-тесту вказує на подальше зменшення функціональних резервів поліморфноядерних нейтрофілів. На це ж вказують і показник резерву та коефіцієнт метаболічної активації нейтрофілів. Це привело до менш інтенсивного продукування активних форм кисню, ніж у перші 24 год експерименту, - показник склав $(0,732 \pm 0,006)$ ум. од., що в 2 рази більше за норму.

На 7-му добу від моменту моделювання гострого поширеного перитоніту еутиреоїдним тваринам співвідношення макрофаги/нейтрофіли було найменшим. Тобто, у вогнищі ураження переважали нейтрофіли, що супроводжувалось розвитком гнійних процесів. Показник сНСТтесту перебував на рівні 4-ї доби, а на тлі подальшого зниження показника іНСТ-тесту значно зменшились показник резерву (до $1,20 \pm 0,04$ ) та коефіцієнт метаболічної активації нейтрофілів (до $0,17 \pm 0,02$ ). На тлі цих процесів зменшувалось і продукування активних форм кисню, хоча порівняно з інтактними тваринами показник склав $187 \%(\mathrm{p}<0,05)$.

До 10-ї доби у тварин, які вижили, спостерігали зростання, порівняно з попереднім терміном спостереження, співвідношення макрофаги/ нейтрофіли до $0,81 \pm 0,07$, що, однак, достовірно менше, ніж у контролі $(1,42 \pm 0,11)$. Суттєво зросли і функціональні резерви поліморфноядерних нейтрофілів - показник резерву склав $1,57 \pm 0,07$, а показник метаболічної активації нейтрофілів - 0,36 $\pm 0,01$, що $є$ позитивною прогностичною ознакою.

У щурів, яким гострий перитоніт моделювали на тлі гіпотиреозу у вогнищі ураження, переважали нейтрофіли, причому їх відсоткове співвідношення було достовірно вищим, ніж у еутиреоїдних тварин, а співвідношення з макрофагами

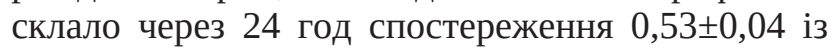
подальшим зростанням до $10-і ̈$ доби $(0,76 \pm 0,06)$. В усі терміни спостереження показник достовірно відрізнявся як від інтактних тварин, так і еутиреоїдних тварин із перитонітом (табл. 1).

В експериментах in vivo та in vitro показано зниження продукції супероксидного аніон-радикала на тлі гіпотиреозу $[11,16]$, що відповідає й отриманим нами результатам (табл. 2). Дослідження функціональної активності нейтрофілів периферійної крові у щурів з перитонітом, що перебігає на тлі гіпотиреозу, показало зниження у них інтенсивності дихального вибуху. В усі терміни спостереження значення як спонтанного, так і стимульованого НСТ-тесту (табл. 2) були нижчими порівняно з тваринами, у яких запальний процес перебігав без зміни гормонального фону. Більш виражене зниження іНСТ-тесту спричинилося до суттєвішого зниження функціональних резервів нейтрофілів порівняно з еутиреоїдними тваринами, а це, у свою чергу, призвело до значно меншого продукування супероксидного аніон-радикала НАДФН-оксидазою нейтрофілів.

Висновки. Дослідження показало, що наявність гіпотиреозу в експериментальних тварин, яким моделювали гострий поширений каловий перитоніт, суттєво впливає на співвідношення кількості фагоцитуючих клітин у місці ушкодження, кисень-залежну біоцидність нейтрофілів, призводить до зниження функціональних резервів фагоцитуючих клітин i, як наслідок, зменшення інтенсивності продукування ними активних форм кисню. 


\section{СПИСОК ЛІТЕРАТУРИ}

1. Распространенный гнойный перитонит / В. В. Бойко, И. Л. Криворучко, С. И. Тесленко, А. В. Сивожелезов. - Х. : Прапор. - 2008. - 278 с

2. Лабораторні методи дослідження у біології, тваринництві і ветеринарній медицині : довідник / [В. В. Влізло, Р. С. Федорук, І. Б. Ратич та ін.]. - Львів : СПОЛОМ, 2012. - 764 с.

3. Дзюбановський I. Я. Синдром поліорганної недостатності та його корекція у хворих на гострий поширений перитоніт / І. Я. Дзюбановський, Б. О. Мігенько // Український Журнал Хірургії. - 2009. - № 2. - С. 56-59.

4. Диагностическая ценность лейкоцитарных тестов. II. Определение биоцидности лейкоцитов : метод. рек. / под ред. Д. Н. Маянского. - Новосибирск, 1996. - 32 с.

5. Экспериментальная модель распространенного калового перитонита / В. А. Лазаренко, В. А. Липатов, Ю. Ю. Блинков, Д. В. Скориков // Человек и его здоровье. - 2008. - № 4. - С. 128-132.

6. Лапач С. Н. Статистические методы в медико-биологических исследованиях с использованием Excel / C. Н. Лапач, А. В. Чубенко, П. Н. Бабич. - К. : Морион, 2000. - 320 с.

7. Науково-практичні рекомендації з утримання лабораторних тварин та роботи з ними / [Кожем’якін Ю. М., Хромов О. С., Філоненко М. А., Сайфетдінова Г. А.]. - К. : Авіцена, 2002. - 156 с.

8. Паньків В. І. Синдром гіпотиреозу / В. І. Паньків // Международный эндокринологический журнал. - 2012. № 5 (45). - С. 136-148.

9. Титов В. Н. Роль макрофагов в становлении воспаления, действие интерлейкина- 1 , интерлейкина- 6 и активность гипоталамо-гипофизарной системы // Клин. лаб. диагн. - 2003. - №12. - C. 3-10.

10. Alberti L. E. Spontaneous bacterial peritonitis in a patient with myxedema ascites / L. E. Alberti, A. Lopez-Gomez, J. J. AlbertiFlor // Digestion. - 2003 - Vol. 68. - P. 91-93.

11. Allen T. Oxidative stress by inorganic arsenic: modulation by thyroid hormones in rat / T. Allen, S. V. Rana // Comp. Biochem.

\section{REFERENCES}

1. Boyko, V.V. Kryvoruchko, I.L., Teslenko, S.I., \& Syvozhelezov, A.V. (2008). Rasprostranennyy gnoynyy perytonit [Common purulent peritonitis]. Kharkov: Prapor [in Russian].

2. Vlizlo, V.V., Fedoruk, R.S., \& Ratych I.B. (2012). Laboratorni metody doslidzhennia u biolohii, tvarynnytstvi $i$ veterynarnii medytsyni: dovidnyk [Laboratory methods in biology, animal husbandry and veterinary medicine: a guide]. Lviv: SPOLOM [in Ukrainian].

3. Dziubanovskyi, I.Ya., \& Mihenko, B.O. (2009) Syndrom poliorhannoi nedostatnosti ta yoho korektsiia u khvorykh na hostryi poshyrenyi perytonit [Organ failure syndrome and its correction in patients with acute peritonitis]. Ukrayinskyi Zhurnal Khirurhii - Ukrainian Journal of Surgery, 2, 56-59. [in Ukrainian].

4. Mayanskyi, D. N. (Ed.). (1996). Diagnosticheskaya tsennost leykotsitarnikh testov. II. Opredeleniye biotsidnosti leykotsitov. Metodicheskiye rekomendatsii. [Diagnostic value of leukocyte tests. II. Determination of biocidal leukocytes. Methodical recommendations]. Novosibirsk [in Russian].

5. Lazarenko, V.A., Lipatov, V.A., Blinkov, Yu.Yu., \& Skorikov, D.V. (2008). Eksperimentalnaya model rasprostranennogo kalovogo peritonita [Experimental model of widespread fecal peritonitis]. Chelovek i yego zdorovye - Man and his health, 4, 128-132 [in Russian].
Physiol. C. Toxicol. Pharmacol. - 2003. - №135. - P. 157-162. 12. Interleukin-18, a proinflammatory cytokine, contributes to the pathogenesis of non-thyroid al illness mainly via the central part of the hypothalamus-pituitary-thyroid axis / A. Boelen, J. Kwakkel, M. Platvoetter Schiphorst [et al.] // Eur. J. Endocrinol. - 2004. - Vol. 151, №4. - P. 497-502.

13. Simult aneouschangesin central and peripheral components of the hypothalamus-pituitary-thyroidaxisin lipopolysaccharideinduced acute illness in mice / A. Boelen, J. Kwakkel, D. C. Thijssen-Timmer [et al.] // J. Endocrinol. - 2004. -Vol. 182, №2. P. 315-323.

14. Blot S. Critical issues in the clinical management of complicated intraabdominal infections / S. Blot, J. J. De Waele // Drugs. - 2005. - № 65 (12). - P. 1611-1620.

15. Isman C. A. Methimazole-induced hypothyroidism in rats ameliorates oxidative injury in experimental colitis / C. A. Isman, B. C. Yegen, I. Alican // J. Endocrinol. - 2003. - Vol. 177, №3. - P. 471-476.

16. Thyroid hormone regulation of cell migration and oxidative metabolism in polymorphonuclear leukocytes: clinical evidence in thyroidectomized subjects on thyroxine replacement therapy / F. Marino, L. Guasti, M. Cosentino [et al.] // Life Sci. - 2006. Vol. 78, №10. - P. 1071-1077.

17. Nongenomic effect of thyroid hormone on free-radical production in human polymorphonuclear leukocytes / E. Mezosi, J. Szabo, E. V. Nagy [et al.] // J. Endocrinol. - 2005. - Vol. 185, №1. - P. 121-129.

18. Pross M. Reduced neutrophil sequestration in lung tissue after laparoscopic lavage in a rat peritonitis model / M. Pross, R. Mantke, D. Kunz // World J. Surg. - 2002. - Vol. 26, No. 1. - P. 49-53. 19. Reed M. Acute Bacterial Peritonitis in Adults / M. Reed, K. Parbadia, J. Cherian // US Pharm. - 2012. - Vol. 37(12). P. HS1-HS8.

20. Rao M. K. Extracellular metabolism of thyroid hormones by stimulated granulocytes / M. K. Rao, A. L. Sagone // Infect. Immun. - 1984. - Vol. 43, №3, P. 846-849.

6. Lapach, S.N., Chubenko, A.V., \& Babich P.N. (2000). Statisticheskiye metody v mediko-biologicheskikh issledovaniyakh $s$ ispolzovaniyem Excel [Statistical methods in biomedical research using Excel]. Kyiv: Morion [in Russian].

7. Kozhemiakin, Yu.M., Khromov, O.S., Filonenko, M.A., \& Saifetdinova, H.A. (2002). Naukovo-praktychni rekomendatsii z utrymannia laboratornykh tvaryn ta roboty z nymy [Scientific and practical advice on keeping laboratory animals and work with them]. Kyiv: Avitsena [in Ukrainian].

8. Pankiv, V.I. (2012) Syndrom hipotyreozu [Hypothyroidism syndrome]. Mezhdunarodnyi endokrynologicheskiy zhurnal - International Endocrinology Journal, 5 (45), 136-148 [in Ukrainian].

9. Titov, V.N. (2003) Rol makrofagov v stanovlenii vospaleniya, deystviye interleykina-1, interleykina-6 i aktivnost gipotalamogipofizarnoy sistemy [The role of macrophages in the formation of inflammation, the effect of interleukin-1, interleukin- 6 and the activity of the hypothalamic-pituitary system]. Klinicheskaya laboratornaya diagnostika - Clinical Laboratory Diagnostics, 12, 3-10 [in Russian].

10. Alberti, L.E., Lopez-Gomez, A., \& Alberti-Flor, J.J. (2003). Spontaneous bacterial peritonitis in a patient with myxedema ascites. Digestion, 68, 91-93.

11. Allen, T., \& Rana, S.V. (2003). Oxidative stress by inorganic 
arsenic: modulation by thyroid hormones in rat. Comp. Biochem. Physiol. C. Toxicol. Pharmacol., 135, 157-162.

12. Boelen, A., Kwakkel J., Platvoetter Schiphorst, M. (2004). Interleukin-18, a proinflammatory cytokine, contributes to the pathogenesis of non-thyroid al illness mainly via the central part of the hypothalamus-pituitary-thyroid axis. Eur. J. Endocrinol., 151 (4), 497-502.

13. Boelen, A., Kwakkel, J., Thijssen-Timmer, D.C. (2004). Simult aneous changes in central and peripheral components of the hypothalamus-pituitary-thyroidaxisin lipopolysaccharide-induced acute illness sin mice. J. Endocrinol., 182 (2), 315-323.

14. Blot, S., \& De Waele, J.J. (2005). Critical issues in the clinical management of complicated intraabdominal infections. Drugs, 65 (12), 1611-1620.

15. Isman, C.A., Yegen, B.C., \& Alican I. (2003). Methimazoleinduced hypothyroidism in rats ameliorates oxidative injury in ex- perimental colitis. J. Endocrinol., 177 (3), 471-476.

16. Marino, F., Guasti, L., \& Cosentino, M. (2006). Thyroid hormone regulation of cell migration and oxidative metabolism in polymorphonuclear leukocytes: clinical evidence in thyroidectomized subjects on thyroxine replacement therapy. Life Sci., 78 (10), 1071-1077. 17. Mezosi, E., Szabo, J., \& Nagy, E.V. (2005). Nongenomic effect of thyroid hormone on free-radical production in human polymorphonuclear leukocytes. J. Endocrinol., 185 (1), 121-129.

18. Pross, M., Mantke, R., \& Kunz, D. (2002). Reduced neutrophil sequestration in lung tissue after laparoscopic lavage in a rat peritonitis model. World J. Surg., 26 (1), 49-53.

19. Reed, M., Parbadia, K., \& Cherian, J. (2012). Acute bacterial peritonitis in adults. US Pharm., 37 (12), 1-8.

20. Rao, M.K., \& Sagone, A.L. (1984). Extracellular metabolism of thyroid hormones by stimulated granulocytes. Infect. Immun., 43 (3), 846-849.

\title{
R. I. VERBA, I. M. KLISHCH
}

I. Horbachevsky Ternopil State Medical University

\section{FEATURES OF OXYGEN-DEPENDENT PROCESSES IN RATS WITH ACUTE PERITONITIS WITH UNDERLYING MERKAZOLIL-INDUCED HYPOTHYROIDISM}

\begin{abstract}
The aim of the work: to study the impact of reduced production of thyroid hormones on the state of oxygen-dependent processes. Materials and Methods. There were used Wistar albino rats. Hypothyroidism was simulated by the injection of Merkazolil at a dose of 25 $\mathrm{mg} / \mathrm{kg}$ for 21 days. Acute peritonitis was simulated by the injection of $0.5 \mathrm{ml}$ of $10 \%$ filtered fecal suspension into the abdominal cavity of studied animals. We determined the ratio of phagocytic cells at the site of injury, production of active oxygen species by the system of phagocytic mononuclears, spontaneous and induced nitroblue tetrazolium test (NBT-test).

Results and Discussion. The study revealed that the presence of hypothyroidism in experimental animals, with simulated acute fecal peritonitis was accompanied by violation of the ratio of phagocytic cells at the site of injury, less pronounced than in euthyroid rats, increasing of active oxygen species and indicators of spontaneous and induced NBT test and, consequently, reduction of their intensity in production of active oxygen species. In the conditions of hypothyroidism oxygen-dependent biocidal activity of neutrophils and functional reserves of phagocytic cells is decreased.
\end{abstract}

Key words: extensive peritonitis; hypothyroidism; oxygen-dependent processes.

\author{
Р. И. ВЕРБА, И. Н. КЛИЩ
}

гВУЗ “Тернопольский государственный медицинский университет имени И. Я. Горбачевского”

\section{ОСОБЕННОСТИ КИСЛОРОД-ЗАВИСИМЫХ ПРОЦЕССОВ У КРЫС С ОСТРЫМ РАСПРОСТРА- НЕННЫМ ПЕРИТОНИТОМ НА ФОНЕ МЕРКАЗОЛИЛИНДУЦИРОВАННОГО ГИПОТИРЕОЗА}

\begin{abstract}
Цель работы: исследование влияния пониженной продукции тиреоидных гормонов на состояние кислород-зависимых процессов.

Материалы и методы. В работе использовали белых крыс линии Вистар. Гипотиреоз моделировали введением мерказолила в дозе 25 мг/кг в течение 21-го дня. Острый распространенный перитонит моделировали введением 0,5 мл 10 \% профильтрованной каловой суспензии в брюшную полость исследуемых животных. Определяли соотношение фагоцитирующих клеток в месте поражения, продуцирование активных форм кислорода системой фагоцитирующих мононуклеаров, спонтанный и индуцированный тест с нитросиним тетразолием (НСТ-тест).

Результаты исследований и их обсуждение. Проведенными исследованиями установлено, что наличие гипотиреоза в экспериментальных животных, которым моделировали острый распространенный каловый перитонит, сопровождалось нарушением соотношения количества фагоцитирующих клеток в месте повреждения, менее выраженным, чем у эутиреоидных крыс, ростом активных форм кислорода, а также показателей спонтанного и индуцированного НСТ-теста и, как следствие, уменьшением интенсивности продуцирования ими активных форм кислорода. В условиях гипотиреоза снижается кислород-зависимая биоцидность нейтрофилов и уменьшаются функциональные резервы фагоцитирующих клеток.
\end{abstract}

Ключевые слова: распространенный перитонит; гипотиреоз; кислород-зависимые процессы. 